\title{
Efektifitas dan efisiensi realisasi anggaran belanja: studi kasus di BAPPEDA Kabupaten Temanggung
}

\author{
Jumaroh ${ }^{1}$, Rr. RetnoSugiharti ${ }^{1}$ * \\ ${ }^{1}$ Fakultas Ekonomi, Universitas Tidar Magelang \\ ${ }^{*}$ Korespondensi (e-mail: retno.sugih arti@untidar.ac.id)
}

\begin{abstract}
Implementing activities or programs in public sector organizations is required to pay attention to the concept of effectiveness and efficiency. The BAPPEDA of Temanggung Regency as one of the public sector units also applies this principle in implementing activities in its environment. Of the units under the Temanggung Regency government, the Temanggung Regency BAPPEDA has the highest budget compared to other OPDs. Therefore, this study aims to analyze the effectiveness and efficiency of implementing the BAPPEDA budget of the Temangg ung Regency. Using the descriptive analysis method, the results of the analysis can be seen that the level of effectiveness and efficiency in the period $2014-2020$ shows varying values. The highest level of effectiveness occurred in 2015 and the lowest occurred in 2016. Implementing expenditure planning for 2014-2020 can be categorized as effective because the programs implemented have been realized. Implementing the 2014-2020 budget, in terms of efficiency, is classified as very efficient. From these results, it can be concluded that the Temanggung Regency BAPPEDA is considered to have carried out budget management very well where the budget management at the Temangg ung Regency BAPPEDA is under the concept of effectiveness and efficiency.
\end{abstract}

Keywords: Budget, Effectiveness, Efficiency

\section{Abstrak}

Pelaksanaan kegiatan atau program pada organisasi sektor publik diharuskan untuk memperhatikan konsep efektivitas dan efisiensi. BAPPEDA Kabupaten Temanggung sebagai salah satu unit sector publik juga menerapkan prinsip tersebut dalam pelaksanaan kegiatan di lingkungannya. Dari unit-unit di bawah pemerintahan Kabupaten Temanggung, BAPPEDA Kabupaten Temanggung memiliki anggaran paling tinggi apabila dibandingkan dengan OPD lainnya. Oleh karena itu, penelitian bertujuan untuk menganalisis efektivitas dan efisiensi pelaksanaan anggaran belanja BAPPEDA Kabupaten Temanggung. Menggunakan metode metode analisis deskriptif, hasil an alisis dap at diketahui bahwa tingkat efektifitas dan efisiensi dalam kurun waktu 2014 -2020 menunjukan nilai yang bervariasi. Tingkat efektivitas tertinggi terjadi di tahun 2015 dan terendah terjadi di tahun 2016. Pelaksanaan perencanaan belanja tahun 2014-2020 dapat dikategorikan telah efektifkarena program yang dijalankan sudah terealisasi. Pelaksanaan anggaran belanja tahun 2014-2020, dari segi efisiensi tergolong sangat efisien. Dari hasil ini dapat disimpulkan bahwa BAPPEDA Kabupaten Temanggung dinilai telah melakukan pengelolaan anggaran belanja dengan sangat baik dimana peng elolaan angg aran belanja pada BAPPEDA Kabupaten Temanggung sudah sesuai dengan konsep efektifitas dan konsep efisiensi

Kata kunci: Ang garan belanja, Efektivitas, Efisiensi

How to cite: Sugihart, R. R., \& Jumaroh, J. (2021). Efektifitas dan efisiensi realisasi anggaran belanja: studi kasus di BAPPEDA Kabupaten Temanggung. Journal of Economics Research and Policy Studies, 1(1), 55-68. 


\section{Pendahuluan}

Berdasarkan Undang-Undang Nomor 23 Tahun 2004 tentang Pemerintahan Daerah, dalam penyelenggaran kegiatan pemerintahan, Pemerintah Daerah berpedoman pada asas penyelenggaraan negara. Kepala Daerah maupun DPRD diberikan kewenangan untuk menyusun, membahas, serta menetapkan Anggaran Pendapatan Belanja Daerah (APBD) dalam keterkaitannya sebagai pelaksana kewenangan daerah otonom. Pemerintah daerah menjadi peran utama dalam pelaksanaan pembangunan ekonomi daerah. Oleh karena itu, pemerintah daerah memiliki tanggung jawab yang penuh atas keadaan perekonomian daerahnya. Bentuk tanggung jawab ini salah satunya pada sumber-sumber penerimaan keuangan daerah. Sumber utama penerimaan keuangan daerah berasal dari Pendapatan Asli Daerah (PAD), dana perimbangan serta penerimaan lain-lain yang wajib dipertanggung jawabkan.

Capaian dalam pengelolaan keuangan dapat dinilai dengan melihat besar kecilnya Pendapatan Asli Daerah (PAD) yang diterima. Nilai PAD yang diperoleh kemudian digunakan sebagai salah satu indikator dalam pengukuran tingkat ketergantungan suatu daerah terhadap pemerintah pusat. Untuk selanjutnya menjadi salah satu bahan evaluasi dan penentuan kebijakan dari pemerintah terhadap pemerintah daerah terakit. Saat nilai PAD terhadap APBD semakin besar, akan menunjukan tingkat ketergantungan daerah terhadap pemerintah pusat yang semakin kecil. Adapun besar kecilnya nilai PAD Kabupaten Temanggung dapat dilihat pada Tabel 1.

Tabel 1. Realisasi PAD Kabupaten Temanggung tahun 2013-2017

\begin{tabular}{lccc}
\hline Tahun & Realisasi PAD & $\begin{array}{c}\text { Realisasi } \\
\text { Pendapatan Daerah }\end{array}$ & Persentase \\
\hline 2013 & 102.080 .197 .094 & 1.003 .617 .112 .969 & 10,17 \\
2014 & 160.726 .943 .432 & 1.182 .627 .603 .285 & 13,59 \\
2015 & 212.498 .139 .929 & 1.423 .975 .845 .171 & 14,92 \\
2016 & 281.328 .148 .970 & 1.623 .136 .823 .357 & 17,33 \\
2017 & 306.787 .002 .252 & 1.777 .882 .944 .063 & 17,26 \\
2018 & 252.019 .934 .778 & 1.731 .168 .366 .276 & 14,56 \\
2019 & 278.306 .408 .650 & 1.840 .953 .306 .303 & 15,12 \\
2020 & 307.431 .698 .576 & 1.830 .789 .907 .558 & 16,79 \\
\hline
\end{tabular}

Sumber:BPPKAD Kabupaten Temanggung, 2020

Dari Tabel 1, menunjukan bahwa nilai realisasi PAD mengalami peningkatan dari tahun ke-tahun selama lima tahun terkahir. Dimana presentase realisasi PAD terhadap pendapatan selama periode tahun 2013 sampai tahun 2020 tecatat meningkat, yaitu dari 10,17 persen menjadi 16,79 persen. Peningkatan nilai PAD ini dapat menjelaskan bahwa Kabupaten Temanggung mampu dan mandiri dalam pengelolaan keuangan daerahnya. Selain itu juga menceminkan bahwa tingkat ketergantungan pada pemerintah pusat semakin kecil. Dengan kata lain, Pemerintah daerah Kabupaten Temanggung mampu meningkatkan sumber penerimaan asli daerah melaui pemetaan atas potensi daerah yang dimiliki. 
Selain Pendapatan, penyelenggaraan pemerintah daerah juga tidak lepas dari adanya penggunaan serta pemanfaatan anggaran. Pada awal periode keuangan, pemerintah daerah selalu mempersiapkan perencanaan anggaran dalam APBD. Secara umum anggaran diartikan sebagai perkiraan ataupun estimasi dari penerimaan yang akan diterima serta pengeluaran yang akan dilakukan untuk melayani kegiatan yang akan dilakukan pada masa mendatang. Menurut Bastian dalam Silalahi (2012), Anggaran dapat digambarkan sebagai paket pertanyaan mengenai perkiraan atau estimasi penerimaan dan pengeluaran yang diharapkan akan terjadi dalam satu atau beberapa periode kedepan.

Dalam Dobell dan Ulrich (2002) dikatakan bahwa anggaran adalah alat utama yang digunakan pemerintah untuk melaksanakan semua janji, kewajiban, dan kebijakannya kedalam rencana-rencana yang kongkrit dan terintegrasi dalam hal tindakan atau kebijakan apa yang akan diambil, hasil seperti apa yang ingin dicapai, pada biaya berapa serta siapa yang akan membiayai. Anggaran sebagai alat perencanaan juga menunjukan target yang harus diraih oleh pemerintah. Selain itu, anggaran sebagai alat pengendalian digunakan juga untuk menunjukan alokasi sumber dana publik yang telah disetujui legislatif untuk dibelanjakan. Dari anggaran untuk masing-masing pos kebutuhan juga dapat terlihat pula apakah anggaran yang dibuat akandapat memiliki manfaat. Hal iniadalah salah satufungsipelaporansebagai pengendali terhadap pelaksanaan kegiatan dan program yang diadakan pemerintah.

Pengelolaan keuangan daerah diatur dalam Peraturan Menteri Dalam Negeri Nomor 13 tahun 2013 pasal 3. Proses pengelolaan keuangan daerah diawali dengan tahap perencanaan atau penyusunan APBD. APBD dibahas dan disetujui bersama oleh pemerintah daerahbersama DPRD. APBD yang telah disetujui kemudian ditetapkan dengan peraturan daerah. APBD berisi kesepakatan bersama antara eksekutif dan legislatif yang kemudian diuraikan dalam peraturan bupati. Penyusunan Anggaran dalam APBD disesuaikan dengan kebutuhan penyelenggaraan pemerintahan dan kemampuan dana yang diperoleh dari pendapatan asli daerah (PAD). Oleh karena itu, setiap komponen pendapatan, belanja dan pembiayaan perlu dilihat seberapa besar realisasi dan kontribusi di setiap periode. Tujuan yang dikehendaki masyarakat yaitu pertanggungjawaban mengenai pelaksanaan value for money. Artinya bahwa pengadaan dan alokasi sumber daya telah dilakukan secara ekonomis, efisien serta efektif dalam mencapai tujuan dan sasaran yang diinginkan.

Tingkat penyerapan anggaran di berbagai wilayah di Indonesia bervariasi, ada yang sudah cukup baik dan ada pula yang masih rendah. Rendahnya tingkat penyerapan anggaran ini, menyebabkan hilangnya manfaat belanja. Hal ini disebabkan karena dana yang telah dialokasikan ternyata tidak dapat semuanya dimanfaatkan. Di sisi lain, terbatasnya sumber penerimaan mengharuskan pemerintah membuat prioritas kegiatan sertapengalokasian anggaran yang efektif dan efisien. Pada Kabupaten Temanggung apabila dilihat struktur APBD, maka tampilannya adalah sebagaiman Gambar 1. 


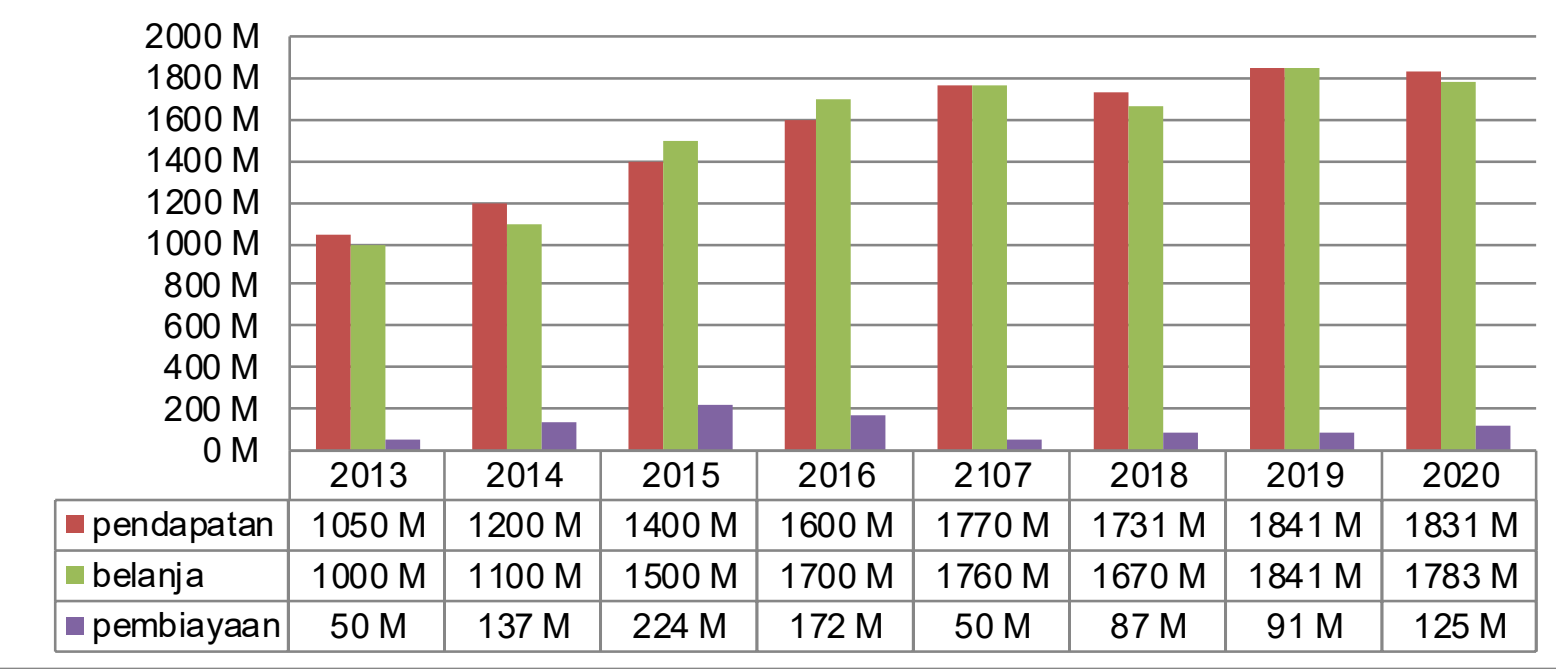

Sumber:BPPKAD Kabupaten Temanggung, 2020

Gambar 1. Struktur Anggaran Pendapatan dan Belanja Daerah Kabupaten Temanggung.

Dari gambar 1 dapat dilihat bahwa pendapatan dan belanja daerah di Kabupaten Temanggung selama lima tahun mengalami tren meningkat. Di sisi lain, pembiayaan daerah di Kabupaten Temanggung cenderung fluktuatif. Berdasarkan gambar 1 dapat dilihat pula bahwa pada tahun 2013, 2014, 208 dan 2020, belanja daerah lebih kecil dibandingkan dengan pendapatan daerahnya, hal ini menunjukan tingkat penyerapan anggaran kurang optimal. Fenomena ini terjadi karena ada beberapa kegiatan dan program yang tidak dapat dilaksanakan akibat terbitnya aturan baru dari pemerintah pusat setelah penetapan APBD.

Efektifitas dan efisiensi pelaksanaan program dan kegiatan memang masih menjadi tantangan dalam pelaksanaan kegiatan/program pemerintah di masa yang akandatang. Salah satusolusi yang dapat dilakukan adalah meningkatkan kerjasama dan integrasi antar Organisasi Pemerintah Daerah (OPD). Badan Perencanaan Pembangunan Daerah (BAPPEDA) Kabupaten Temanggung juga telah melakukan kerjasama secara horizontal dengan Organisasi Pemerintah Daerah (OPD) di lingkukan Pemerintahan Kabupaten Temanggung yaitu Dinas Pendidikan, Pemuda dan Olahraga (DINDIKPORA); Dinas Perhubungan, Komunikasi dan Infomasi (DISHUBKOMINFO); Dinas Kependudukan dan Catatan Sipil (DISDUKCAPIL); Dinas Pendapatan, Pengelolaan Keuangan dan Aset Daerah (DPPKAD); Dinas Tenaga Kerja; Dinas Sosial; Dinas Kesehatan;Dinas Pekerjaan Umum Perumahan dan Kawasan Pemukiman (DPUPKP);serta masih banyak Organisasi Pemerintah Daerah (OPD) yang lainnya. Kerjasama merupakan pokok yang penting dalam penguatan lembaga, termasuk dalam pelaksanaan program dan kegiatan pemerintahan. Dengan adanya koordinasi antar Organisasi Pemerintah Daerah (OPD) akan berpengaruh pada efektifitas dan efisiensi program dan kegiatan dimana anggaran dapat terserap dengan optimal.

Pentingnya efektifitas dalam pengelolaan anggaran mulai dari penyusunan anggaran, sampai dengan pertanggungjawaban/pelaporan anggaran akan berdampak pada akuntanilitas pemerintah, yang berhubungan dengan fungsi 
pemerintah dalam memberikan pelayanan kepada masyarakat. Pengelolaan anggaran yang efektif dan efisien ini juga muaranya akan dirasakan langsung oleh masyarakat Kabupaten Temanggung. Output utama adalah dengan terserapnya anggaran sesuai dengan target yang ditentukan serta akan terciptanya good govermance atau tata kelola pemerintahan yang baik.

Namun pada kenyataannya, baik di daerah provinsi maupun kabupaten serta organisasi publik penyerapan anggaran tidak selalu mencapai target yang telah ditetapkan dalam APBD. Hal ini menyiratkan bahwa kurangnya tingkat efektifitas maupun efisiensi dalam pengelolaan anggaran di berbagai daerah yang juga terjadi di Kabupaten Temanggung. Di Kabupaten Temanggung, peningkatan capaian PAD tiap tahunnya menggambarkan pengelolaan keuangan di kabupaten Temanggung telah mampu dan optimal. Namun disisi lain, apabila dilihat dari nilai anggaran, Bappeda Kabupaten Temanggung memiliki nilai anggaran yang cukup besar dari Organisasi Pemerintah Daerah yang lain. Hal tersebut ditunjukan pada Tabel 2.

Tabel 2. Ringkasan APBD menurut Organisasi Pemerintah Daerah (Tahun Anggaran 2014)

\begin{tabular}{|c|c|c|c|c|}
\hline \multirow{2}{*}{ No } & \multirow{2}{*}{$\begin{array}{c}\text { Organisasi Pemerintah } \\
\text { Daerah (OPD) }\end{array}$} & \multicolumn{3}{|c|}{ Belanja } \\
\hline & & Tidak Langsung & Langsung & Jumlah Belanja \\
\hline 1. & $\begin{array}{l}\text { Dinas Lingkungan } \\
\text { Hidup (DLH) }\end{array}$ & Rp1.760.917.405 & Rp7.412.991.600 & Rp9.173.909.005 \\
\hline 2. & $\begin{array}{l}\text { Dinas Perhubungan, } \\
\text { Komunikasi dan } \\
\text { Informasi } \\
\text { (DISHUBKOMINFO) }\end{array}$ & Rp3.140.753.983 & Rp2.755.460.000 & Rp5.896.213.983 \\
\hline 3. & $\begin{array}{l}\text { Dinas Kependudukan } \\
\text { dan Catatan Sipil } \\
\text { (DISDUKCAPIL }\end{array}$ & Rp2.357.049.424 & Rp2.535.696.250 & Rp4.892.745.674 \\
\hline 4. & $\begin{array}{l}\text { Badan Perencanaan } \\
\text { Pembangunan Daerah } \\
\text { (BAPPEDA) }\end{array}$ & Rp2.251.502.545 & Rp9.519.240.000 & Rp11.770.742.545 \\
\hline 5. & Dinas Sosial (Dinsos) & Rp1.992.637.292 & Rp4.097.120.300 & Rp6.089.757.592 \\
\hline
\end{tabular}

Sumber: Lampiran II Penetapan perda Kabupaten Temanggung APBD No. 17 Tahun 2013.

Jika dibandingkan dengan Organisasi Pemerintah Daerah (ODP) lain, Badan Perencanaan Pembangunan Daerah (BAPPEDA) memiliki Jumlah belanja yang lebih besar. Yaitu sebesar Rp 11.770.742.545 dengan rincian Belanja langsung sesesar Rp 9.519.240.000 dan belanja tidak langsung sebesar Rp 2.251.502.545. Anggaran Belanja Bappeda Kabupaten Temanggung tersebut bahkan dua kali lipat dari anggaran OPD lainnya seperti Dinas Perhubungan, Komunikasi dan Informasi (DISHUBKOMINFO) yang jumlah anggarannya hanya sebesar Rp 5.896.213.983 dan anggaran Dinas Kependudukan dan Catatan Sipil (DISDUKCAPIL) dengan nilai total anggaran belanjanya sebesar Rp 4.892.745.674. Fakta tersebut menggining pada partanyaan apakah dengan anggaran tertinggi dari OPD lainnya, Bappeda Kabupaten Temanggung telah efektif dan efisien dalam pengelolaan keuangannya? Tentu dengan anggaran yang lebih besar dari Organisasi Pemerintah Daerah (ODP) lainnya, Bappeda Kabupaten Temanggung dalam pelaksanaan program maupun 
kegiatan diharapkan sudah memperhatikan konsep efektivitas dalam hal mencapai tujuan ataupun sasaran serta efisiensi dalam pemanfaatan sumber daya dengan penyerapan anggaran yang optimal.

Badan Perencanaan Pembangunan Daerah (BAPPEDA) Kabupaten Temanggung adalah lembaga teknis dengan tupoksi (tugas pokok dan fungsi) yang berfokus pada aspek terbentuknya proses perencanaan pembangunan. Maka sangat penting bagi Bappeda Kabupaten Temanggung untuk melaksanakan berbagai penetapan analisis dalam penggunaan anggaran dan belanja yang ada dengan memperhatikan pedoman pembentukan penyusunan supaya terlaksana keefisien serta keefektifan dalam realisasi anggaran yang telah ditetapkan.

Penelitian tentang Efektifitas dan Efisiensi Pengelolaan atau realisasi anggaran telah banyak dilakukan sebelumnya. Diantaranya penelitian yang dilakukan oleh Julita (2011), yang hasilnya menyatakan bahwa tingkat efektifitas anggaran pendapatan pada Badan Lingkungan Hidup Provinsi Sumatera Utara tahun 2009 sampai 2012 dinilai sangat efektif. Sedangkan hasil tingkat efisiensi anggaran pendapatan pada Badan Lingkungan Hidup Provinsi Sumatera Utara tahun 2009 sampai 2012 dinilai sangat efisien dalam pengelolaan anggaran belanja. Penelitian serupa telah dilakukan oleh Sumenge (2013) dengan judul Analisis Efektifitas dan Efisiensi Pelaksanaan Anggaran Belanja Badan Perencanaan Pembangunan Daerah (BAPPEDA) Minahasa Selatan. Sumenge (2013) membuktikan bahwa tingkat dan kriteria efektifitas anggaran belanja pada BAPPEDA Minahasa Selatan tahun 2008 sampai 2012 sangat bervariasi dan secara keseluruhan anggaran belanja pada BAPPEDA Minahasa Selatan tahun 2008 sampai 2012 sudah diolah secara efsien.

Penelitian tentang efektifitas dan efisiesi pada OPD elain BAPPEDA juga telah dilakukan pada Dinas Kebudayaan dan Pariwisata Provinsi Sulawesi Utara (Pangkey dan Pinatik, 2015). Dalam penelitiannya, dapat diperoleh hasil yang menunjukan bahwa pada Dinas Kebudayaan dan Pariwisata Provinsi Sulawesi Utara dalam kurun waktu tahun 2010 sampai 2014 tidak dan tidak efisien secara keseluruhan dalam pelaksanaan anggaran belanjanya. Kajian lain tentang efektifitas dan efisiensi dilakukan oleh Rampengan, Nangoi dan Manossoh (2016) dengan judul Analisis Efektifitas Dan Efisiensi Pelaksanaan Anggaran Belanja Badan Perencanaan Pembangunan Daerah (Bappeda) Kota Manado. Dalam kajian mereka memberikan kesimpulan bahwa Efektifitas Anggaran Belanja Bappeda Kota Manado memilliki kriteria efektifitas yang bervariasi selama kurun waktu tahun 2011 sampai 2015 dan efisiensi anggaran belanja Bappeda Kota Manado dinilai sudah efisien. Penelitian di Kota Palembang juga telah dilakukan oleh Azmi dan Jusmani (2017) yang memberikan hasil bahwa kriteria efektifitas anggaran pada Bappeda Kota Palembang tahun 2013 sampai 2015 dapat dinilai cukup efktif. Di Kota Tomohon juga telah dilakukan penelitian tentang efektifitas dan efisiensi anggaran oleh Paat, Nangoi, dan Pusung (2019) dengan judul Analisis Efektivitas Dan Efisiensi Pelaksanaan Anggaran Belanja Badan Perencanaan Penelitian Dan Pengembangan Daerah Kota Tomohon dan memperoleh hasil yang menyatakan bahwa secara 
keseluruhan periode anggaran dari tahun 2015 sampai 2017 pada Kota Tomohon sudah dinilai baik dan presentase tingkat efisiensi mengalami fluktuasi.

Penelitian mengenai efektifitas dan efisiensi juga dilakukan oleh sari, Mintari, dan pattisahusiwa (2018) dengan judul analisis efektifitas dan efisiensi pelaksanaan anggaran. Penelitian mereka membuktikan bahwa di Kota Samarinda tingkat atau kriteria efektifitas belanjanya dari tahun 2011 sampai 2015 dinilai bervariasi dan pelaksanaan anggaran pemerintah Kota Samarinda secara keseluruhan dinilai sudah efisien. Penilaian atas efektifitas dan efisiensi pengelolaan anggaran memang telah banyak dilakukan, namun penelitian tentang efektifitas dan efisiensi anggaran dengan objek pemerintahan Kabupaten Temanggung belum banyak dilakukan. Oleh karena itu, penelitian ini bertujuan untuk mengetahui efektivitas dan efisiensi pelaksanaan anggaran belanja pada Bappeda Kabupaten Temanggung.

\section{Metode Penelitian}

Untuk mengetahui tingkat efektifitas dan tingkat efisiensi realisasi anggaran belanja di Bappeda Kabupaten Temanggung, pada penelitian ini dilakukan dengan menggunakan metode analisis deskriptif. Penelitian deskriptif adalah penelitian yang dilakukan untuk mengetahui nilai variabel mandiri, baik dengan satu variabel atau lebih dan tanpa membuat suatu perbandingan maupun mengubungkan antara variabel satu dengan variabel yang lain. Sugiyono (2016) menerangkan bahwa analisis deskriptif ialah analisis statistik yang digunakan untuk menganalisis dengan cara mendeskripsikan data yang telah terkumpul dan tanpa bemaksud untuk membuat kesimpulan yang berlaku untuk um um (generalisasi).

Analisis deskriptif digunakan untuk mengetahui rasio efektitas dan efisiensi realisasi anggaran pada Bappeda Kabupaten Temanggung. Kedua rasio tersebut dapat diketahui melalui rumusan berikut.

\section{Tingkat Efektifitas Anggaran Belanja}

Efektifitas merupakan perbandingan antara target (hasil yang diharapkan) dengan realisasi hasil yang dicapai. Suatu kegiatan atau program dapat dinilai efektif jika output yang dihasilkan dapat memenuhi tujuan dan sasaran yang diharapkan, dengan kata lain anggaran telah digunakan dengan tepat (spending wisely) (Mahmudi,2018).

Menurut Mardiasmo (2009) Efektifitas merupakan pencapaian target output yang diukur dengan menggunakan perbandingan Output Anggaran (OA) dengan output realisasi (OS), apabila OA>OS maka dikatakan efektif. Hal penting yang perlu di garisbawahi bahwa efektifitas tidak menyatakan besar biaya yang dikeluarkan untuk mencapai tujuan yang diinginkan, namun hanya melihat apakah suatu kegiatan atau program telah mencapai tujuan yang telah diharapkan. Tingkat efektifitas diukur dengan cara membandingkan antara nilai realisasi anggaran belanja dengan nilai target anggaran belanja (Mahsun, 2013). 


$$
\text { Efektifitas }=\frac{\text { Realisasi anggaran belanja }}{\text { Target anggaran belanja }} \times 100 \%
$$

Anggaran belanja dikatakan efektif apabila memenuhi kriteria efektifitas dalam keputusan Menteri Dalam Negeri tentang Kriteria Penilaian dan Kinerja Keuangan disajikan dalam Tabel 3.

Tabel 3. TingkatEfektifitas

\begin{tabular}{cl}
\hline Tingkat Efektifitas & \multicolumn{1}{c}{ Penilaian } \\
\hline$>100 \%$ & SangatEfektiff \\
$90 \%-100 \%$ & Efektif \\
$80 \%-90 \%$ & Cukup Efektiff \\
$60 \%-80 \%$ & Kurang Efektif \\
$<60 \%$ & Tidakk Efektif \\
\hline Sumber: Kemendagri Nomor690.900.327,1996
\end{tabular}

Dengan cara ini, maka dapat dihitung tingkat efektifitaas pengelolan anggaran Kabupaten temanggung dilihat dari laporan realisasi Anggaran pada Bappeda Kabupaten Temanggung.

\section{Tingkat Efisiensi Anggaran Belanja}

Efisiensi merupakan capaian yang dilakukan demi menghasilkan output yang maksimal dengan penggunaan dan pengelolaan sumber daya (dana) yang seminimal mungkin. Dengan kata lain, efisiensi merupakan hubungan antara output berupa barang dan jasa yang dihasilkan dari suatu kegiatan dengan input atau sumber daya yang digunakan dengan tidak membuang tenaga, biaya serta waktu dengan percuma.

Efisiensi mempunyai hubungan yang erat dengan konsep produktifitas. Efisiensi diukur dengan menggunakan perbandingan antara nilai realisasi anggaran belanja langsung dan nilai realisasi anggaran belanja (Mahsun, 2013). Dengan hal ini, tingkat efisiensi dari anggaran belanja Bappeda Kabupaten Temanggung dapat dihitung menggunakan perbandingan antara nilai nominal dalam realisasi anggaran belanja langsung dengan nilai nominal realisasi anggaran belanja melalui rumus berikut:

$$
\text { Efisiensi }=\frac{\text { Realisasi anggaran belanja langsung }}{\text { Realisasi anggaran belanja }} \times 100 \%
$$

Anggaran belanja dikatakan efisien apabila memenuhi kriteria efisiensi dalam keputusan Menteri Dalam Negeri tentang Kriteria Penilaian dan Kinerja Keuangan disajikan dalam Tabel 4 .

Tabel 4. Tingkat Efisiensi

\begin{tabular}{cl}
\hline Tingkat Efisiensi & Penilaian \\
\hline$>100 \%$ & Tidak Efisien \\
$90 \%-100 \%$ & Kurang Efisien \\
$80 \%-90 \%$ & Cukup Efisien \\
$60 \%-80 \%$ & Efisien \\
$<60 \%$ & SangatEfisien \\
\hline
\end{tabular}

Sumber:Kemendagri Nomor690.900-327, 1996 
Data yang digunakan dalam penelitian ini adalah data kuantitatif. Menurut Kuncoro (2009), data kuantitatif merupakan data yang diukur dalam suatu skala angka-angka atau numerik. Ada dua cara dalam tahap pengumpulan data dalam penelitian ini, yaitu melalui studi kepustakaan (library research) dan melalui cara dokumentasi. Studi kepustakaan adalah studi dimana data yang digunakan bersifat kajian teoriteori lewat buku, artikel, serta browsing lewat intemet yang kemudian dijadikan landasan teoritis dan sebagai pendukung terkait pemasalahan yang akan diteliti. Sedangkan cara dokumentasi adalah cara pengumpulan data yang diperoleh dari dokumen atau catatan yang tersimpan, berupa laporan realisasi anggaran Bappeda Kabupaten Temanggung tahun 2015-2017.

\section{Hasil dan Pembahasan}

\subsection{Hasil penelitian}

Efektifitas dan efisiensi anggaran belanja adalah salah satu prinsip yang sangat penting dalam penyelenggaraan anggaran belanja pada suatu organisasi sektor publik. Hal ini bertujuan supaya pelayanan dan kesejahteraan yang diberikan kepada masyarakat dapatmaksimal.

\section{Tingkat Efektifitas Anggaran Belanja}

Penilaian Tingkat efektifitas dilakukan dengan mengetahui capaian pelaksanaan program atau kegiatan dibandingkan dengan target yang seharusnya dicapai. Perhitungan yang dilakukan adalah dengan membandingkan nilai realisasi anggaran belanja dan target anggaran belanja yang tercatat laporan realisasi anggaran pada Bappeda Kabupaten Temanggung. Maka diperoleh hasil perhitungan rasio efektifitas dalam pelaksanaan anggaran pada Bappeda Kabupaten Temanggung yang tertuang dalam Tabel 5.

Tabel 5. Laporan realisasi Anggaran pada Bappeda Kabupaten Temanggung

\begin{tabular}{|c|c|c|c|c|}
\hline Tahun & $\begin{array}{l}\text { Realisasi Anggaran } \\
\text { Belanja }\end{array}$ & $\begin{array}{c}\text { Target Anggaran } \\
\text { Belanjaa }\end{array}$ & Efektifitas & Penilaian \\
\hline 2014 & Rp 11.954.836.055 & Rp 10.579.439.340 & $88 \%$ & Efektif \\
\hline 2015 & $\operatorname{Rp} \quad 9.460 .782 .418$ & $\operatorname{Rp} \quad 6.491 .808 .410$ & $69 \%$ & Kurang Efektif \\
\hline 2016 & Rp 20.883.337.100 & Rp 19.389.188.251 & $93 \%$ & Efektif \\
\hline 2017 & Rp 13.591.282.638 & Rp 12.878.078.437 & $95 \%$ & Efektif \\
\hline 2018 & Rp 10.819.446.656 & Rp 10.326.855.889 & $95 \%$ & Efektif \\
\hline 2019 & Rp 10.745.811.657 & Rp 9.996.362.355 & $93 \%$ & Efektif \\
\hline 2020 & Rp 7.419.367.462 & Rp $\quad 6.780 .353 .496$ & $91 \%$ & Efektif \\
\hline
\end{tabular}

Sumber: Data diolah, 2020.

\section{Tingkat Efisiensi Anggaran Belanja}

Dengan melihat perbandingan antara nilai realisasi belanja langsung dan Realisasi belanja pada Bappeda Kabupaten Temanggung, maka dapat diukur tingkat efesiensi anggaran belanja Bappeda Kabupaten Temanggung dengan menggunakan Laporan Realisasi anggaran pada Bappeda Kabupaten Temanggung. Hasil perhitungan rasio efisiensi dalam pelaksanaan anggaran pada Bappeda Kabupaten Temanggung tertuang dalam Tabel 6

Tabel 6. Laporan realisasi Anggaran pada Bappeda Kabupaten Temanggung 


\begin{tabular}{|c|c|c|c|c|}
\hline Tahun & $\begin{array}{l}\text { Realisasi Belanja } \\
\text { Langsung }\end{array}$ & Realisasi Belanja & Efisiensi & Penilaian \\
\hline 2014 & $\operatorname{Rp} 8.442 .280 .686$ & Rp 10.579.439.340 & $80 \%$ & Cukup Efisien \\
\hline 2015 & Rp $\quad 5.750 .688 .133$ & Rp 6.491.808.410 & $89 \%$ & Cukup Efisien \\
\hline 2016 & Rp 16.479.170.005 & Rp 9.389.188.251 & $85 \%$ & Cukup Efisien \\
\hline 2017 & Rp $\quad 9.983 .596 .480$ & Rp 3.591.282.638 & $73 \%$ & Efisien \\
\hline 2018 & Rp 9.359.167.245 & Rp 2.878.078.437 & $73 \%$ & Efisien \\
\hline 2019 & Rp 5.663 .810 .271 & Rp 9.996.362.355 & $57 \%$ & Sangat Efisien \\
\hline 2020 & Rp 2.262 .557 .833 & Rp 6.780.353.496 & $33 \%$ & Sangat Efisien \\
\hline
\end{tabular}

Sumber: Laporan realisasi Anggaran (Data Olahan) pada Bappeda Kabupaten Temanggung

\subsection{Pembahasan}

\section{Tingkat Efektifitas Anggaran Belanja}

Berdasarkan hasil perhitungan pad Tabel 5, terlihat bahwa tingkat efektifitas pelaksanaan anggaran belanja pada Bappeda Kabupaten Temanggung tahun 20142020 berfluktuasi tiap tahun ke tahun berikutnya. Pada tahun 2014 tingkat efektifitas berada pada presentase 88 persen, hal ini menunjukan angka realisasi sebesar Rp 11.954.836.055 dapat dikategorikan dikatakan efektif.

Efektifitas pada tahun 2015 mengalami penurunan yaitu sebesar 19 persen dengan capaian efektifitas sebesar $69 \%$ dan berada pada angka realisasi Rp 9.460.782.418, sehingga pada tahun tersebut anggaran dinilai Kurang efektif. Penurunan rasio efektifitas ini dikarenakan kurangnya efektifitas pendalaman dan perumusan program kegiatan yang ada dalam perencanaan. Hal lain yang melatarbelakangi penurunan rasio efektifitas pada tahun ini yaitu kurangnya kreatifitas dan inovasi dalam pelaksanaan program dan juga kegiatan yang telah disusun. Hal ini didoreong pula dengan keterbatasan kapasitas sumber daya manusia (SDM) dalam menerapkan program dan kegiatan pembangunan yang efektif. Pada tahun selanjutnya, yakni tahun 2016 terjadi peningkatan sebesar 24 persen dengan nilai efektifitas sebesar 93 persen yang berada pada angka realisasi sebesar Rp 20.883.337.100. Pada tahun 2016 rasio efektifitasnya lumayan tinggi dengan presentase 93\% hal ini menunjukan pada tahun 2016 kemampuan dan kinerja Bappeda Kabupaten Temanggung dikatakan baik dalam mengelola keuangan di lingkungan Bappeda Kabupaten Temanggung. Pada tahun selanjutnya yaitu 20172020 rasio efektifitasnya cenderung naik menjadi 95\% di tahun 2017 dan 2018 , 93\% di tahun 2019, serta $91 \%$ di tahun 2020 . Dalam masa empat tahun tersebut pelaksanaan anggaranya juga masih dalam kriteria yang efektif. Peningkatan rasio pada empat tahun terakhir ini menandakan bahwa Bappeda Kabupaten Temanggung dalam pengelolaan keuangan khususnya anggaran menunjukan kinerja yang semakin baik.

Maka dapat disimpulkan bahwa pengelolaan anggaran belanja pada Bappeda Kabupaten Temanggung memiliki tingkat efektifitas yang bervariasi dalam kurun periode tahun 2014 sampai tahun 2020. Tingkat efektifitas anggaran belanja 
Bappeda Kabupaten Temanggung pada tahun 2014 berada dalam kriteria efektif, karena capaian realisasi anggaran pada tahun ini sangat sedikit perbedaanya dengan target anggaran yang telah ditetapkan. Tingkat efektifitas terendah selama periode 2014 sampai 2018 terjadi ditahun 2015 dimana tingkat efektifitasnya sebesar 69 persen, sehingga pada tahun tersebut anggaran dinilai Kurang efektif. Hal ini terjadi dikarenakan ada faktor-faktor yang menyebabkan beberapa program ataupun kegiatan yang tidak tercapai dengan penuh sesuai dengan target yang telah ditetapkan sebelumnya.

Di tahun 2016 tingkat efektifitas anggaran dinilai sudah efektif dengan presentase capaian sebesar 93 persen. Dimana pada tahun 2016 ini, realisasi anggaran sudah sesuai dengan anggaran yang ditetapkan. Sedangkan pada tahun 2017 sampai tahun 2020 pengelolaan anggaran belanja berada dalam kriteria efektif dengan presentase 90 persen keatas yang artinya realisasi anggaran pada keempat tahun terakhir tersebut telah mendekati nilai target yang ditetapkan. Adanya perbedaan antara nilai realisasi dengan target yang di harapkan disebabkan oleh beberapa faktor. Faktor utama adalah adanya kegiatan yang telah dianggarkan, namun tidak dilaksanakan. Namun secara keseluruhan, kegiatan serta program lain yang dianggarkan sudah dilaksanakan secara efektif. Dikatakan juga bahwa beberapa kegiatan yang diprogramkan sudah terealisasi dan sesuai dengan yang diinginkan, serta dikatakan sudah sangat efektif.

\section{Tingkat Efisiensi Anggaran Belanja}

Dari Tabel 6, hasil perhitungan yang telah dilakukan maka dapat tingkat efisiensi anggaran belanja di Bappeda Kabupaten Temanggung dari tahun 2014 sampai tahun 2020 secara keseluruhan berfluktuatif. Pada tahun 2014, tingkat efisiensi berada pada level 80 persen. Pada titik tersebut tingkat efisiensi dikatakan dalam kriteria yang cukup efisien. Pada tahun-tahun selanjutnya terjadi penurunan tingkat efisiensi. Hal ini terlihat dari nilai presentase yang semakin naikl dan menunjukan bahwa tingkat efisiensi semakin menurun dari tahun ke tahun. Pada tahun 2015, tingkat efisiensi lebih tinggi dari tahun sebelumnya, yaitu sebesar 89 persen, dimana tahun sebelumnya sebesar 80 persen. Peningkatan tingkat efisiensi terjadi lagi di tahun 2016, yaitu sebesar 4 persen. Meskipun peningkatan secara rasio dapat dikatakan kecil, namun hal ini cukup baik karena secara tidak langsung telah ada harapan semakin meningkat lagi rasio efisiensi anggaran belanja pada Bappeda Kabupaten Temanggung ditahun selanjutnya. Dan benar, pada tahun selanjutnya, yakni tahun 2017 sampai tahun 2020 tingkat efisiensi anggaran meningkat secara terus menerus.

Tingkat efisiensi anggaran belanja pada Bappeda Kabupaten Temanggung dinilai sudah dalam kriteria yang cukup baik, dimana berdasarkan tabel diatas dapat dilihat bahwa dari tahun 2014 sampai tahun 2020 berada dalam kriteria yang selalu membaik hingga ditahun 2019 dan 2020 tingkat efifiensinya tergolong sangat efisien. Tingkat efisiensi anggaran belanja dihitung dan berpatokan dengan hal biaya. Tingkat efisiensi ditentukan dengan ketepatan dalam memanfaatkan anggaran 
belanja dengan menentukan prioritas pada faktor input, yang dimana dapat mengacu pada pencapaian terhadap tujuan serta sasaran tertentu.

Bappeda Kabupaten Temanggung dikatakan sudah sesuai dengan pengertian dan konsep efisiensi, dimana Bappeda Kabupaten Temanggung telah berhasil melaksanakan berbagai program dengan menggunakan dana seminimal mungkin untuk pencapaian hasil yang maksimal. Beberapa kegiatan yang dianggarkan dan masuk dalam anggaran belanja langsung pada Bappeda Kabupaten Temanggung diantaranya: 1) Program Pelayanan Administrasi Perkantoran. 2) Program peningkatan sarana dan prasarana aparatur. 3) Program Peningkatan Pengembangan sistem Pelaporan capaian Kinerja dan Keuangan. 4) Program Pengembangan data/infomasi. 5) Program kerjasama Pembangunan. 6) Program Perencanaan Pembangunan daerah. 7) Program Perencanaan Sosial Budaya. 8) Program Perencanaan Prasarana wilayah dan Sumber Daya Alam. 9) Program Penelitian dan Pengembangan. 10) Program Pengembangan data/informasi/statistik daerah.

Sesuai dengan konsep dan Pengertian dari efekttifitas yakni menggunakan dana yang seminimal mungkin untuk mendapatkan hasil yang maksimal. Sehingga dapat dikatakan bahwa Bappeda Kabupaten Temanggung sudah memenuhi konsep tingkat efektifitas yang baik yang direpreentasikan oleh 10 program yang telah dijalankan. Bappeda Kabupaten Temanggung juga telah berhasil menggunakan anggaran yang seminimal mungkin dan mendapatkan hasil yang maksimal. Sedangkan beberapa yang masuk dalam biaya tidak langsung pada Bappeda Kabupaten Temanggung yaitu: Belanja pegawai yang terdiri dari gaji dan tunjangan, serta tambahan penghasilan PNS.

Selain dengan melihat dari sisi laporan realisasi anggaran pada Bappeda Kabupaten Temanggung, Indikator Kinerja Sasaran (IKS) juga dibentuk untuk melihat tingkat keefektifan dan tingkat efisiensi, serta dampak dari semua pelaksanaan program pembangunan yang dilakukan. Ada sebanyak 52 IKS (Indikator Kinerja Sasaran) yang tercantum dalam RPJMD Kabupaten Temanggung saat ini. Beberapa diantaranya ialah 1) Indikator Pembangunan Pemuda; 2) Indikator Toleransi; 3) Indikator Gotong Royong; 4) Indikator Rasa Aman; serta masih ada 48 Indikator kinerja sasaran (IKS) yang lainya. Maka dari itu disarankan untuk penelitian selanjutnya menilai rasio efektifitas, rasio efisiensi, serta dampak dari pelaksanaan program maupun kegiatan yang dilakukan pemerintah maupun Organisasi Pemerintah Daerah (OPD) yang ada di Kabupaten Temanggung dan/atau daerah lain dengan menggunakan penilaian Indikator Kinerja Sasaran (IKS). Kajian tersebut tentunya diharapkan mampu merespon penilaian keberhasilan rencana pembangunan daerah Kabupaten Temanggung. Selain itu, hasil dari kajian IKS dapat menjadi masukan dalam perumusan program/ kebijakan yang relevan kepada Pemerintah Kabupaten Temanggung dengan meningkatkan capaian kinerja penyelenggaraan pemerintah Kabupaten Temanggung serta untuk mencapai tujuan good govemance (tata kelola pemerintahan yang baik) pada umumnya, dan pada 
khususnya untuk meningkatkan pembangunan dan kesejahteraan masyarakat Kabupaten Temanggung secara berkelanjutan.

\section{Kesimpulan}

Pelaksanaan anggaran pada Bappeda Kabupaten Temanggung dari tahun 2014 sampai tahun 2018 dikatakan efektif serta sangat efisien secara keseluruhan. Dimana secara nominal tingkat efektitas anggaran pada Bappeda Kabupaten Temanggung dari tahun 2014 sampai tahun 2018 sangat berfluktuasi. Tingkat efektifitas tertinggi terjadi pada tahun 2015 dan yang terendah terjadi pada tahun 2016 dengan presentase. Pada tahun 2017 dan 2018 tingkat efektifitas anggaran belanja dinilai sudah dalam kriteria efektif dengan presentase keduanya diatas 97 persen. Tingkat efektifitas belum maksimal sebab adanya perbedaan antara nilai realisasi dengan target yang di harapkan. Ini terjadi karena adanya kegiatan yang telah dianggarkan, namun tidak dilaksanakan. Akan tetapi secara keseluruhan beberapa kegiatan yang diprogramkan oleh Bappeda Kabupaten Temanggung sudah terealisasi dan telah sesuai dengan target yang diinginkan, dan dinilai sudah sangatefektif.

Pengelolaan Anggaran Belanja pada Bappeda Kabupaten Temanggung dari tahun 2014 sampai tahun 2020 dikatakan sudah sangat efisien yaitu berada dalam presentase dibawah $40 \%$ mendekati angka 30\%. Dimana terus mengalami peningkatan rasio efisiensi dari setiap tahun ketahun berikutnya. Hal ini cukup untuk membuktikan bahwa Bappeda Kabupaten Temanggung dinilai telah melakukan pengelolaan anggaran belanja dengan sangat baik dimana pengelolaan anggaran belanja pada Bappeda Kabupaten Temanggung sudah sesuai dengan pengertian dan konsep efisiensi, yakni berhasil menggunakan anggaran dengan seminimal mungkin untuk pencapaian hasil yang maksimal.

\section{Ucapan Terimakasih}

Peneliti mengucapkan banyak terimakasih kepada pihak-pihak yang telah membantu terselesaikannya penelitian ini.

\section{Referensi}

Agustono. (2013). Analisis Sektor Pertanian Ditinjau Dari Peran Terhadap Pertumbuhan Dan Stabilitas Produk Domestik Regional Bruto Di Provinsi Jawa Tengah. Sepa, 9(2), 283-296.

Azmi \& Jusmani. (2017). Analisis Efektifitas Pelaksanaan Anggaran Belanja (Badan Perencanaan Pembangunan Daerah Penelitian Dan Pengembangan (Bappeda Litbang) Kota Palembang, Jurnal Media Wahana Ekonomika, Vol. 14 No.2

BAPPEDA. (2019.) Laporan Realisasi Anggaran Belanja tahun 2014-2018. Kabupaten Temanggung.

Dinas Pendapatan, Pengelolaan Keuangan dan Aset Daerah (DPPKAD) Kabupaten Temanggung. 2017. Realisasi PAD Kabupaten Temanggung.

Dinas Pendapatan, Pengelolaan Keuangan dan Aset Daerah (DPPKAD) Kabupaten Temanggung. 2017. Struktur Anggaran Pendapatan dan Belanja Daerah (APBD) 
Kabupaten Temanggung.

Dobell, P., \& Ulrich, M. (2002). Parliament's Perfomace In The Budget Procces: A Case Study. Policy Matters 3(2): 1-24.

Julita, M. (2020). Analisis Efektivitas Dan Efisiensi Anggaran Pendapatan Dan Belanja Pada Badan Lingkungan Hidup Provinsi Sumatera Utara. Jurnal umsu, Vol. 10 No. 2 (2011)

Kuncoro, M. (2009). Metode Riset untuk Bisnis \& Ekonomi. Edisi 3. Erlangga. Jakarta.

Mahmudi. (2018). Akuntansi SektorPublik. Edisi Revisi. UII Press, Yogyakarta.

Mardiasmo. (2009). Akuntansi SektorPublik. Andi. Yogyakarta

Mahsun, M. (2013). Pngukuran Kinerja Sektor Publik. Yogyakarta; BPFE

Paat, Nangoi, dan Pusung. (2019) . Analisis Efektivitas Dan Efisiensi Pelaksanaan Anggaran Belanja Badan Perencanaan Penelitian Dan Pengembangan Daerah Kota Tomohon. Jurnal EMBA

Pangkey \& Pinatik. (2015). Analis Efektivitas dan Efisiensi Anggaran Belanja pada Dinas Kebudayaan Dan Pariwisata Provinsi Sulawesi Utara. Jurnal EMBA. Vol. 3 No. 4 Hal 33-43

Peraturan Daerah Kabupaten Temanggung Nomor 17 Tahun 2013 Tentang Anggaran Pendapatan dan Belanja Daerah (APBD) Tahun 2014.

Permendagri Nomor 13 tahun 2013 tentang Pedoman Pengelolaan Keuangan Daerah.

Rampengan, Nangoi, \& Manossoh. (2016). Analisis Efektifitas Dan Efisiensi Pelaksanaan Anggaran Belanja Badan Perencanaan Pembangunan Daerah (Bappeda) Kota Manado. Jurnal Berkala IImiah Efisiensi. Vol. 16 No. 03

Republik Indonesia. Peraturan Menteri Dalam Negeri Nomor 690.900-327 tahun 1996 tentang Kriteria Penilaian dan Kinerja Keuangan. Jakarta.

Sari, M., \& Pattisahusiwa. (2018). Analisis Efektifitas dan Efisiensi pelaksanaan Anggaran Belanja. Jurnal Ekonomi dan Manajemen. Vol. 15 No. 1

Silalahi, S. P. (2012). Pengaruh Anggaran Berbasis Kinerja, Sistem Akuntansi Keuangan Daerah, dan Sistem Informasi Pengelolaan Keuangan Daerah Terhadap Penilaian Satuan Kerja Perangkat Daerah (Studi Pemerintah di Kota Dumai). Jurnal Ekonomi, Vol. 20 No. Hal 1-20.

Sugiyono. (2016). Metode Penelitian (Pendekatan Kuantitatif, Kualitatif dan R\&D). Bandung; Alfabeta

Sumenge, A. S. (2013), Analisis Efektivitas dan Efisiensi Pelaksanaan Anggaran Belanja Badan Perencanaan Pembangunan Daerah (BAPPEDA) Mibahasa Selatan, Jurnal EMBA, Vol. 1 No. 3 hal 74-81

Undang-Undang Nomor 23 Tahun 2004 tentang Pemerintahan Daerah. Jakarta, Direktorat Jenderal Otonomi Daerah. 